\title{
Issues associated with formula milk: the Hong Kong's experience
}

\author{
Kam-Lun Hon, Ting-Fan Leung \\ Hong Kong, China
}

A 1though advocated by physicians and allied health staff, success rates of breastfeeding remain low in the city of Hong Kong. Conversely, the problems with formula milk and products plague the city from time to time and generate huge fuss and uncertainty to fretful parents.

\section{Melamine threat}

News broke in September 2008 that many young children had developed kidney problems after consuming melamine-tainted milk products in mainland China ${ }^{[1,2]}$ The company that produced the infant formula, Sanlu Group Co., was China's biggest producer of powdered milk and was $43 \%$ owned by a New Zealand dairy farmers' cooperative, Fonterra. The incident was failure for China's product safety system. Almost 12900 children were hospitalized and six deaths had been related to contamination of infant formula. In China, the addition of melamine increased the level of nitrogen which masqueraded as falsely high protein. Meanwhile, the Hong Kong government utilized huge resources in mass screening mostly asymptomatic individuals to reassure the public. The pick-up rate for kidney stones was less than one in a thousand, and the chances of Hong Kong citizens being affected were very low. ${ }^{[3]}$ Anyhow, 18 designated clinics provided initial assessment to nearly 55 thousand patients, while nine assessment centres attended to 25 000 thousand patients.

\footnotetext{
Author Affiliations: Department of Pediatrics, 6/F Prince of Wales Hospital, the Chinese University of Hong Kong, Shatin, Hong Kong, China (Hon KL, Leung TF)

Corresponding Author: Kam-Lun Ellis Hon, MBBS, MD, FAAP, FCCM, Department of Pediatrics, the Chinese University of Hong Kong, 6/F, Clinical Sciences Building, Prince of Wales Hospital, Shatin, Hong Kong, China (Tel: 852-2632-2859; Fax: 852-2636-0020; Email: ehon@cuhk.edu. hk)

doi: 10.1007/s12519-014-0446-4

(C)Children's Hospital, Zhejiang University School of Medicine, China and Springer-Verlag Berlin Heidelberg 2014. All rights reserved.
}

\section{Radiations threat}

Sale of Japanese formula milk products rocketed to 5.4 million kilograms per annum in Hong Kong in 2010. In March 2012, following the Japanese tsunami and radiation leak, "radiation" was found to be present in baby milk formula. Customers in Hong Kong queued to buy pre-tsunami Japanese milk formula in a rush to beat the potential effects of radiation contamination. ${ }^{[4]}$ Some Hong Kong parents swore that they would continue with the expensive Japanese products despite unfamiliar content and radiation risks.

\section{Iodine threat}

In August 2012, Hong Kong health chiefs urged parents not to feed their babies brands of Japanese milk formula after they were found to have low iodine content. ${ }^{[5]}$ Parents were urged to switch to other brands or breastfeeding as a "precautionary measure". The Department of Health was prompt to provide blood tests at 10 maternal and child health centres for babies aged one to eight months who had been fed the Japanese brands. Japan has no legal requirements for iodine content in formula milk. Since then Japanese formula milk products have lost their glorious times in Hong Kong. Instead, unfamiliar Korean formula product might have picked up the sale and become popular.

\section{Supply threat}

In early 2013, infant formula shortage plagued Hong Kong again as many parallel traders hand-carried cans of formula milk to mainland cities to resell at high profit margins. This attractive commodity was available in the mainland but fear of quality control and scandals have rendered mainland parents to rather pay high price for products "imported" from Hong Kong. Some irate Hong Kongers even sought to appeal for "international aid" from United States President Barack Obama against mainland "smugglers" in a petition on the White House website. The Hong Kong government responded to assure parents as it moved to crack down on enterprising mainland parallel traders exploiting a legal 
loophole. Anyone leaving Hong Kong was only allowed to take two cans (or up to $1.8 \mathrm{~kg}$ ) of milk powder with them. Milk powder is treated like heroin or illicit drugs. The regulations have been successful.

\section{Botulism threat}

In August 2013, Fonterra in New Zealand suddenly urged a recall of milk products containing whey protein concentrate produced in May 2012 at a New Zealand manufacturing site that had been contaminated with clostridium botulinum. The company apparently found "signs" of the presence of clostridium botulinum in a sample with some unconventional testing (sulphite reducing clostridia, SRC). The New Zealand Ministry of Primary Industries said that six other countries were affected: Australia, China, Malaysia, Saudi Arabia, Thailand and Vietnam. Huge publicity was generated in the city of Hong Kong again. The Department of Health announced that recall of these contaminated products had begun but the risk was low. Meanwhile, local experts gave detailed description on media to the public that clostridium spore is everywhere also in Hong Kong soil; and the spore and the toxin are resistant to high temperature treatment, and infant botulism is a serious disease that may cause respiratory failure and death, especially in infants. Some also debated if equine botulinum antitoxin be used for infants in case of an outbreak in Hong Kong instead of BabyBIG ${ }^{\circledR}$.6,7] BabyBIG $^{\circledR}$ is available as a public-service orphan drug for infants in the United States, but is not immediately available in Hong Kong. ${ }^{[6]}$ It is recommended that treatment with BabyBIG ${ }^{\mathbb{B}}$ be given as soon as possible after hospital admission and should not be delayed for confirmatory testing of feces or enema. ${ }^{[7]}$ This would potentially mean that many infants with "probably" infantile botulism (infants on the culprit milk formula with a little bit of tiredness or constipation but anxious parents) will have to be treated without delay for shipping of the vaccine or confirmatory testing. In practice, unfortunately, this will not be possible regardless of the cost of the vaccine.

Interestingly, countries in our vicinity such as
Singapore and Malaysia did not seem to be bothered by such a fuss. Even more strange, there had been no report of any case of clostridium botulism. Nor was the level of spores or toxins tested or mentioned in any reports. Indeed, there had been no bug, spore, toxin or patients to date. The aftermath is just a big fuss and many anxious parents. Issues with infant milk formula are no small-potato matter and generate many public health challenges from time to time.

Pediatricians and physicians caring for infants and children should keep ourselves up-to-date with contemporary issues associated with infant formula milk so that we can give timely information to illadvised and often fretful parents.

Funding: None.

Ethical approval: Not applicable.

Competing interest: None.

Contributors: Both authors have contributed equally to this paper.

\section{References}

1 Parry J. China's tainted infant formula sickens nearly 13000 babies. BMJ 2008;337:a1802.

2 Hon KL. Melamine-tainted milk: When China sneezes, Hong Kong catches cold. Indian J Pediatr 2010;77:109-110.

3 Lam HS, Ng PC, Chu WC, Wong W, Chan DF, Ho SS, et al. Renal screening in children after exposure to low dose melamine in Hong Kong: cross sectional study. BMJ 2008;337:a2991.

4 South China Morning Post, 2011. www.scmp.com/ article/741057/radiation-fears-cause-rush-japanese-milk-formula (accessed November 29, 2013).

5 South China Morning Post, 2012.www.scmp.com/ article/1014363/parents-warned-milk-formula (accessed November 29, 2013).

6 Vanella de Cuetos EE, Fernandez RA, Bianco MI, Sartori OJ, Piovano ML, Lúquez C, et al. Equine botulinum antitoxin for the treatment of infant botulism. Clin Vaccine Immunol 2011;18:1845-1849.

7 Arnon SS, Schechter R, Maslanka SE, Jewell NP, Hatheway CL. Human botulism immune globulin for the treatment of infant botulism. N Engl J Med 2006;354:462-471.

Received November 29, 2013 Accepted after revision December 15, 2013 